\title{
Antioxidant Enzymes Respond to Osmotic Stress in the Leaves of Sugarcane (Saccharum officinarum L.)
}

\author{
C. L. Pote ${ }^{1}$, P. S. Chougule ${ }^{1 *}$, D. V. Shirsat ${ }^{2}$, A. A. Kale ${ }^{1,2^{*}}$, R. M. Naik ${ }^{1}$, \\ A. S. Jadhav ${ }^{2}$, R. M. Garkar ${ }^{3}$ and C. A. Nimbalkar ${ }^{4}$ \\ ${ }^{1}$ Department of Biochemistry, Post Graduate Institute, ${ }^{2}$ State Level Biotechnology Center, \\ Mahatma Phule Krishi Vidyapeeth, Rahuri, Maharashtra, India \\ ${ }^{3}$ Central Sugarcane Research Station, Padegoan, Dist. Satara, Maharashtra, India \\ ${ }^{4}$ Department of Statistics, Post Graduate Institute, Mahatma Phule Krishi Vidyapeeth, Rahuri, \\ Maharashtra, India \\ *Corresponding author
}

Keywords

Antioxidents, CAT, APX, SOD,

Sugarcane, Osmotic Stress

\section{Article Info}

Accepted:

12 November 2019

Available Online:

10 December 2019

\section{A B S T R A C T}

Sugarcane is (Saccharum officinarum L.) is one of the most important commercial crops of the world, including region where water availability is limited or highly inconsistent. Abiotic stresses may decline in potential yield of crop plants by $70 \%$. In sugarcane numerous environmental factors can have negative effects on the increase in expansion of production and salinity stress is one of the most limiting abiotic factors affecting sugarcane productivity. Two sugarcane varieties viz., MS-10001 and CoC-671 were sown in the pots and were evaluated for antioxidative enzymes activity of Ascorbate peroxidase (APX), Catalase (CAT) and Superoxide Dismutase (SOD) under different salt stress levels $\left(0,2,4,8 \mathrm{dSm}^{-1}\right)$. The activity of antioxidative enzymes APX was recorded highest in MS-10001 at (2, 4, 8 dSm-1) salt stresses and less per cent increase was found in APX activity in CoC-671 at different salt stress level. The activity of antioxidative enzymes Superoxide dismutase and catalase was recorded higher in MS-10001 as compared to CoC-671.

\section{Introduction}

Sugarcane (Saccharum officinarum L.) is a major sugar producing plant. It is also a high biomass producer and consumes large amounts of water and nutrients from the soil for achieving maximum productivity. At harvest of the total above ground dry biomass, 
sugarcane stalks account for about $75 \%$ and the leaves and tops around $25 \%$. A sugarcane of 12 months age will have around 69-75\% water, $8-16 \%$ sugars, $8-16 \%$ fiber, $0.5-1.0$ $\%$ nitrogen, $0.3-0.8 \%$ ash, $0.5-2.0 \%$ reducing sugars, $0.2-0.6 \%$ inorganic compounds (phosphates, chlorides, sulphates etc.), and $0.5-1.0 \%$ (organic compounds proteins, organic acids, pigments etc). The composition of sugarcane juice at maturity have around 70-80 \% water, $18-22 \%$ sucrose, $2-4 \%$ glucose, $2-4 \%$ fructose, $1.5-4.5 \%$ salts of inorganic acids, $1.0-3.0 \%$ salts of organic acid, $0.1-0.5 \%$ carboxylic acids, $0.5-$ $2 \%$ of amino acids $0.5-0.6 \%$ proteins, $0.01-$ $0.05 \%$ starch (Parthasarathy, 1972). Originating in Asia, sugarcane is highly productive in the tropical and sub-tropical areas of the world. However, the adverse environmental conditions affect the growth and development of sugarcane plants (Lisson et al., 2005). Abiotic stress such as high salinity, drought extreme temperature are major cause of crop loss worldwide, reducing average yields for most of the crop plants by more than $50 \%$. High salt concentrations decrease the osmotic potential of soil solution creating a water stress in plants and also cause severe ion toxicity, saline $\mathrm{Na}^{+}$is not readily sequestered into vacuoles as in halophytes. Salt stress consists of two components, like, osmotic stress caused by the increase in external osmotic pressure due to high external concentration of salt and the physiological and biochemical effect of cations and anions on plant cell (Munns and Termaat, 1986).

The salt tolerant mechanisms of plants can be broadly described as ion homeostasis, osmotic homeostasis, stress damage control and repair and growth regulation. Hence, the salt tolerant plants besides being able to regulate the ion and water movements also have an efficient antioxidative system for effective removal of the reactive oxygen species (ROS). Plants protect cells and sub-cellular systems from the effects of ROS by antioxidant enzymes such as superoxide dismutase (SOD), catalase, peroxidase, glutatione reductase, polyphenol oxidase and non enzymic antioxidants such as ascorbate and glutathione (Agarwal and Pandey, 2004). APX is one of the most important antioxidant enzymes of plants that detoxify $\mathrm{H}_{2} \mathrm{O}_{2}$ using ascorbate for reduction. In different plant species, APX activity increased in response to a variety of biotic and abiotic stresses (Gomathi et al., 2012). APX enzyme is involved in protecting the oxidative damage, such as hydrogen peroxide generated in the chloroplast. CAT enzyme is involved in protecting the oxidative damage, such as hydrogen peroxide generated in the chloroplast (Kraus et al., 1995). CAT is important for the elimination of $\mathrm{H}_{2} \mathrm{O}_{2}$. Several studies have reported that salinity may induce increase in CAT activity (Dermiral and Turkan, 2005; Sekmen et al., 2007).

\section{Materials and Methods}

\section{Planting material and stress treatment}

The planting material of two sugarcane cultivars, MS-10001 a salinity tolerant and CoC-671 a salinity sensitive were obtained from Central Sugarcane Research Station, Padegaon, Dist. Satara. The sets were planted in a plastic pots containing black soil in three replicates for each treatment and grown in the control conditions in green house. After 60 days after planting the stress treatment was imposed with $\mathrm{NaCl}$ solution of concentration $0,2,4,8 \mathrm{dSm}^{-1}$.

\section{Preparation of enzyme extract}

Antioxidative enzymes such as superoxide dismutase (SOD) and ascorbate peroxidase (APX) were extracted from stress and unstressed leaf of sugarcane by using the method of Costa et al., (2002). The leaves were homogenized with a pestle in a chilled 
mortar with $2 \mathrm{ml}$ of an ice-cold $0.1 \mathrm{mM}$ potassium phosphate buffer ( $\mathrm{pH}$ 7.5) containing $1 \mathrm{mM}$ EDTA, $1 \mathrm{mM}$ PMSF and 5 $\%$ (w/v) PVPP. The homogenates were filtered through four layers of cheese cloth and then centrifuged at $4^{\circ} \mathrm{C}$ for $20 \mathrm{~min}$ at $15,000 x g$. The supernatant fraction was used as crude extract for enzyme activity assays.

\section{Estimation of Ascorbate peroxidase (APX) activity}

Ascorbate peroxidase activity was measured immediately in fresh extract which was assayed as per the method described by Nakano and Asada (1987). $3 \mathrm{ml}$ enzyme reaction mixture contained $50 \mathrm{mM}$ phosphate buffer (pH 7.0), $0.5 \mathrm{mM}$ ascorbic acid, $3 \mathrm{mM}$ EDTA and $50 \mu \mathrm{l}$ enzyme extract. The reaction was initiated by the addition of $0.3 \mathrm{ml}$ of 1 $\mathrm{mM} \mathrm{H} \mathrm{H}_{2} \mathrm{O}_{2}$. The hydrogen peroxide dependent oxidation of ascorbic acid was followed by a decrease in the absorbance measured at 290 $\mathrm{nm}$ for three min at the interval of $30 \mathrm{sec}$. The enzyme activity was expressed as nmoles of MDAA formed $\min ^{-1} \mathrm{~g}^{-1}$ fresh weight (FW) by considering $2.8 \quad \mathrm{mM} \quad \mathrm{cm}^{-1}$ extinction coefficient of MDAA.

\section{Estimation of Catalase (CAT) activity}

Catalase activity was measured immediately in fresh extract and the assay as described by Aebi (1984). The hydrogen peroxide dependent oxidation was estimated by the decrease in absorbance at $240 \mathrm{~nm} .3 \mathrm{ml}$ enzyme reaction mixture contained $50 \mathrm{mM}$ potassium phosphate buffer $(\mathrm{pH} 7.0)(1.5 \mathrm{ml}$ of $100 \mathrm{mM}$ ), $100 \mu \mathrm{l}$ enzyme extract, $0.9 \mathrm{ml}$ of distilled water and $12.5 \mathrm{mM}$ hydrogen peroxide $(0.5 \mathrm{ml}$ of $75 \mathrm{mM})$. The reaction was initiated with addition of $0.5 \mathrm{ml}$ of $75 \mathrm{mM}$ $\mathrm{H}_{2} \mathrm{O}_{2}$. For measurement of catalase enzyme activity, the decline in absorbance was recorded at $240 \mathrm{~nm}$ for three min at an interval of $30 \mathrm{sec}$. The amount of hydrogen peroxide decomposed was determined from molar extinction coefficient ( $\left.\varepsilon 36 \mathrm{M}^{-1} \mathrm{~cm}^{-1}\right)$. The enzyme activity was expressed as $\mu$ moles of $\mathrm{H}_{2} \mathrm{O}_{2}$ decomposed $\mathrm{mg}^{-1} \mathrm{~g}^{-1} \mathrm{FW}$.

\section{Estimation of Superoxide dismutase (SOD) activity}

Superoxide dismutase activity was determined by measuring its ability to inhibit the photochemical reduction of nitroblue tetrazolium using the method described by Dhindsa et al., (1981). $3 \mathrm{ml}$ enzyme reaction mixture contained $1.5 \mathrm{ml}$ of $100 \mathrm{mM}$ phosphate buffer ( $\mathrm{pH} 7.8$ ), $75 \mu \mathrm{M}$ NBT, $2 \mu \mathrm{M}$ riboflavin, $13 \mathrm{mM}$ methionine, 0.1mM EDTA, and $100 \mu 1$ enzyme extract. The riboflavin was added at last. The reaction was started by switching on light (two bulbs of $15 \mathrm{~W}$ ) and after 15 min reaction was terminated by switching off light and covering the tubes with black cloth. The non-irradiated reaction mixture without enzyme extract kept in dark served as control. After $10 \mathrm{~min}$ tubes containing reaction mixture was spinned for 510 seconds and absorbance read at $560 \mathrm{~nm}$ using control as a blank. One unit of SOD was defined as the amount of enzyme required to cause 50 per cent inhibition of NBT reduction per min at $560 \mathrm{~nm}$.

\section{Results and Discussion}

The ascorbate peroxidase activity of control and salt stressed plants of two sugarcane varieties are shown in Table 1. The salt stressed leaves showed increase in ascorbate peroxidase activity over unstressed control plants of two sugarcane varieties. A salinity tolerant sugarcane variety MS10001 had ascorbate peroxidase activity was 0.63 nmoles of MDAA formed $\min ^{-1} \mathrm{~g}^{-1}$ fr. wt. at $0 \mathrm{dSm}^{-1}$ (control), and 0.67 nmoles of MDAA formed $\min ^{-1} \mathrm{~g}^{-1}$ fr. wt. at $2 \mathrm{dSm}^{-1}, 0.77$ nmoles of MDAA formed $\min ^{-1} \mathrm{~g}^{-1}$ fr. wt. at $4 \mathrm{dSm}^{-1}$, 0.83 nmoles of MDAA formed $\min ^{-1} \mathrm{~g}^{-1}$ fr. wt. 
at $8 \mathrm{dSm}^{-1}$. Whereas, $\mathrm{CoC} 671$ ascorbate peroxidase activity was 0.46 nmoles of MDAA formed $\min ^{-1} \mathrm{~g}^{-1}$ fr. wt. at $0 \mathrm{dS} \mathrm{m}{ }^{-1}$ (control), and 0.53 nmoles of MDAA formed $\min ^{-1} \mathrm{~g}^{-1}$ fr. wt. at $2 \mathrm{dSm}^{-1}, 0.54$ nmoles of MDAA formed $\min ^{-1} \mathrm{~g}^{-1}$ fr. wt. at $4 \mathrm{dSm}^{-1}$, 0.66 nmoles of MDAA formed $\min ^{-1} \mathrm{~g}^{-1}$ fr. wt. at $8 \mathrm{dSm}^{-1}$. Thus it was observed that the salinity tolerant MS 10001 variety had higher activity of APX at each of salt stress condition than the salt susceptible $\mathrm{CoC} 67$ sugarcane variety. APX is one of the most important antioxidant enzymes of plants that detoxify $\mathrm{H}_{2} \mathrm{O}_{2}$ using ascorbate for reduction.

The oxidative enzymes, ascorbate peroxidase are reported to increase under the influence of high salinity (Venkataramana et al., 1997; Shalata and Tal, 1998). In different plant species, APX activity increased in response to a variety of biotic and abiotic stresses (Gomathi et al., 2012). APX enzyme are involved in protecting the oxidative damage, such as hydrogen peroxide generated in the chloroplast (Kraus et al., 1995) Plants have developed several antioxidative defense against excessive ROS production generated by salinity (Sairam and Tyagi, 2004; Miller $e t$ al., 2010). Chugh et al., (2011) reports that an increase in APX activity was observed in LM5 and Parkash (tolerant genotypes) in response to drought stress, whereas activity of APX declined in sensitive genotypes (PMH2, JH3459, Paras and LM14) under stress. Karpe et al., (2012) carried out comparative study to assess salt stress response of sugarcane varieties. In this study it was reported that several fold of higher APX activity in salt tolerant genotype than salt susceptible genotype. The decrease in APX activity in sugarcane salt susceptible genotypes implies a decline in the free radical scavenging ability which leads to enhancement of free radical levels in cells that associated with more LPO resulting in cell membrane damage and ion efflux due to salinity stress. The LPO and membrane damage in flooded corn leaves was induced mainly by O2- (Bin et al., 1996). Concomitant results are obtained in the present study.

The catalase activity of control and salt stressed plants of two sugarcane varieties are presented in Table 1. The stressed leaves showed increase in catalase content over unstressed control of two sugarcane varieties.

The salt tolerant MS10001 sugarcane variety had higher activity of CAT at each level of imposed salt stress than the $\mathrm{CoC} 671$ salt susceptible variety. Catalase activity in MS 10001 variety was 34.35 umoles of $\mathrm{H}_{2} \mathrm{O}_{2}$ decomposed $\min ^{-1} \mathrm{~g}^{-1}$ fr. wt. at $0 \mathrm{dS} \mathrm{m}^{-1}$ (control), 36.38 umoles of $\mathrm{H}_{2} \mathrm{O}_{2}$ decomposed $\min ^{-1} \mathrm{~g}^{-1}$ fr. wt. at $2 \mathrm{dS} \mathrm{m}^{-1}, 40.19$ umoles of $\mathrm{H}_{2} \mathrm{O}_{2}$ decomposed $\min ^{-1} \mathrm{~g}^{-1}$ fr. wt. at $4 \mathrm{dS} \mathrm{m}^{-1}$, 55.70 umoles of $\mathrm{H}_{2} \mathrm{O}_{2}$ decomposed $\min ^{-1} \mathrm{~g}^{-1}$ fr. wt. at $8 \mathrm{dS} \mathrm{m}^{-1}$. Whereas in CoC 671 variety it was 26.65 umoles of $\mathrm{H}_{2} \mathrm{O}_{2}$ decomposed $\mathrm{min}^{-1}$ $\mathrm{g}^{-1}$ fr. wt. at $0 \mathrm{dS} \mathrm{m}^{-1}$ (control), 34.43 umoles of $\mathrm{H}_{2} \mathrm{O}_{2}$ decomposed $\min ^{-1} \mathrm{~g}^{-1}$ fr. wt. at $2 \mathrm{dS}$ $\mathrm{m}^{-1}$, 41.46 umoles of $\mathrm{H}_{2} \mathrm{O}_{2}$ decomposed $\mathrm{min}^{-1}$ $\mathrm{g}^{-1}$ fr. wt. at $4 \mathrm{dS} \mathrm{m}{ }^{-1}, 49.83$ umoles of $\mathrm{H}_{2} \mathrm{O}_{2}$ decomposed $\min ^{-1} \mathrm{~g}^{-1}$ fr. wt. at $8 \mathrm{dS} \mathrm{m}^{-1}$.

The harmful effects of ROS are prevented by the presence of antioxidant enzyme such as catalase (CAT, EC 1.11.1.6), present in plant cells (Pagariya et al., 2012 and Desikan et al., 2004). Increased activities of antioxidant enzyme CAT which act as a damage control system and thus provide protection from oxidative stress, otherwise, which would cause damage of cell membrane and protein, DNA structure and inhibit the photosynthesis as reported under water stress condition (Sairam and Saxena, 2000; Sairam and Tyagi, 2004). Patade et al., (2011) reported that the CAT activity did not differ significantly in stressed and control plants. 
Table.1 Effect of induced salinity stress on Ascorbate peroxidase, catalase and superoxide dismultase in salinity tolerant and salinity susceptible sugarcane varieties

\begin{tabular}{|c|c|c|c|c|c|c|c|c|c|c|c|c|c|}
\hline \multirow[t]{3}{*}{$\begin{array}{l}\text { Sr. } \\
\text { No. }\end{array}$} & \multirow[t]{3}{*}{ Varieties } & \multicolumn{4}{|c|}{$\begin{array}{l}\text { APX (nmoles of MDAA formed } \\
\left.\min ^{-1} \mathrm{~g}^{-1} \text { fr. wt. }\right)\end{array}$} & \multicolumn{4}{|c|}{$\begin{array}{c}\text { CAT ( } \mu \text { moles of } \mathrm{H}_{2} \mathrm{O}_{2} \\
\text { decomposed } \text { min }^{-1} \mathrm{~g}^{-1} \text { fr. wt.) }\end{array}$} & \multicolumn{4}{|c|}{ SOD (units $\mathrm{mg}^{-1}$ protein) } \\
\hline & & \multicolumn{12}{|c|}{ Stress Level $\left(\mathrm{dS} \mathrm{m}^{-1}\right)$} \\
\hline & & $\mathbf{0}$ & 2 & 4 & 8 & $\mathbf{0}$ & 2 & 4 & 8 & $\mathbf{0}$ & 2 & 4 & 8 \\
\hline & \multicolumn{13}{|c|}{ Salinity Tolerant Variety } \\
\hline \multirow[t]{2}{*}{1.} & MS10001 & $\begin{array}{c}0.63 \\
(0)\end{array}$ & $\begin{array}{c}0.67 \\
(6.35)\end{array}$ & $\begin{array}{c}0.77 \\
(22.22)\end{array}$ & $\begin{array}{c}0.83 \\
(31.75)\end{array}$ & $\begin{array}{l}34.35 \\
(0)\end{array}$ & $\begin{array}{l}36.38 \\
(5.91)\end{array}$ & $\begin{array}{c}40.19 \\
(16.99)\end{array}$ & $\begin{array}{c}55.70 \\
(62.16)\end{array}$ & $\begin{array}{c}82.72 \\
(0)\end{array}$ & $\begin{array}{l}93.03 \\
(12.46)\end{array}$ & $\begin{array}{l}114.40 \\
(38.29)\end{array}$ & $\begin{array}{r}144.10 \\
(74.20)\end{array}$ \\
\hline & \multicolumn{13}{|c|}{ Salinity Susceptible Variety } \\
\hline \multirow[t]{6}{*}{2.} & CoC671 & $\begin{array}{c}0.46 \\
(0)\end{array}$ & $\begin{array}{c}0.53 \\
(15.22)\end{array}$ & $\begin{array}{c}0.54 \\
(17.39)\end{array}$ & $\begin{array}{c}0.66 \\
(43.48)\end{array}$ & $\begin{array}{l}26.65 \\
(0)\end{array}$ & $\begin{array}{c}34.43 \\
(29.21)\end{array}$ & $\begin{array}{c}41.46 \\
(55.56)\end{array}$ & $\begin{array}{c}49.83 \\
(86.98)\end{array}$ & $\begin{array}{c}78.68 \\
(0)\end{array}$ & $\begin{array}{c}90.40 \\
(14.90)\end{array}$ & $\begin{array}{l}108.02 \\
(37.29)\end{array}$ & $\begin{array}{l}\mathbf{1 2 0 . 4 5} \\
(\mathbf{5 3 . 0 9 )}\end{array}$ \\
\hline & \multicolumn{13}{|c|}{ Interaction between varieties and treatment } \\
\hline & Comparison & \multicolumn{2}{|c|}{ S.E. \pm} & \multicolumn{2}{|c|}{$\mathrm{CD}$ at $5 \%$} & \multicolumn{2}{|c|}{ S.E. \pm} & \multicolumn{2}{|c|}{$\mathrm{CD}$ at $5 \%$} & \multicolumn{2}{|c|}{ S.E. \pm} & \multicolumn{2}{|c|}{ CD at $5 \%$} \\
\hline & Variety & \multicolumn{2}{|c|}{$0.00 \overline{5}$} & \multicolumn{2}{|c|}{0.017} & \multicolumn{2}{|c|}{$0.12 \overline{4}$} & \multicolumn{2}{|c|}{0.381} & \multicolumn{2}{|c|}{0.648} & \multicolumn{2}{|c|}{1.998} \\
\hline & Treatments & \multicolumn{2}{|c|}{0.008} & \multicolumn{2}{|c|}{0.024} & \multicolumn{2}{|c|}{0.175} & \multicolumn{2}{|c|}{0.539} & \multicolumn{2}{|c|}{0.917} & \multicolumn{2}{|c|}{2.825} \\
\hline & $\begin{array}{c}\text { Variety } x \\
\text { Treatment }\end{array}$ & \multicolumn{2}{|c|}{0.011} & \multicolumn{2}{|c|}{0.034} & \multicolumn{2}{|c|}{0.247} & \multicolumn{2}{|c|}{0.762} & \multicolumn{2}{|c|}{1.297} & \multicolumn{2}{|c|}{3.996} \\
\hline
\end{tabular}

\footnotetext{
*Values in parenthesis indicates \% increase over control
} 
Chugh et al., (2011) reported that the drought stress stimulated the CAT activity in maize crop by $46 \%$ and $14 \%$ in LM5 and Parkash genotypes, whereas a significant decrease of 37, 29, 15 and $24 \%$ was observed in $\mathrm{PMH} 2$, JH3459, Paras and LM14, respectively.

The superoxide dismutase activity of control and salt stressed plants of two sugarcane varieties are tabulated in Table 1. The stressed leaves showed increase in superoxide dismutase content over unstressed control plants of two sugarcane varieties. A salt tolerant sugarcane MS10001 variety had superoxide dismutase activity 82.72 units $\mathrm{mg}^{-1}$ protein at $0 \mathrm{dSm}^{-1}$ (control), 93.03 units $\mathrm{mg}^{-1}$ protein at $2 \mathrm{dSm}^{-1}, 114.40$ units $\mathrm{mg}^{-1}$ protein at $4 \mathrm{dSm}^{-1}, 144.10$ units $\mathrm{mg}^{-1}$ protein at $8 \mathrm{dSm}^{-1}$. Whereas, salt tolerant sugarcane CoC 671 variety had superoxide dismutase activity 78.68 units $\mathrm{mg}^{-1}$ protein at $0 \mathrm{dSm}^{-1}$ (control), 90.40 units $\mathrm{mg}^{-1}$ protein at $2 \mathrm{dSm}^{-1}, 108.02$ units $\mathrm{mg}^{-1}$ protein at $4 \mathrm{dSm}^{-1}, 120.45$ units $\mathrm{mg}^{-}$ ${ }^{1}$ protein at $8 \mathrm{dSm}^{-1}$. It was revealed that tolerant MS 10001 variety had more SOD activity than susceptible CoC 671 variety at all the imposed $\mathrm{NaCl}$ stress.

Gomathi et al., (2011) reported that in control SOD activity showed increasing trend with the age in all the genotypes of sugarcane. However, the genotype response was almost identical in all the stages. Under salinity condition, a clear cut genotypic variation in SOD activity was noticed and it showed increasing trend up to GPP and it declined towards maturity phase. The Co 85004 and C 92038 which is salinity tolerant were recorded higher in the enzyme activity in all the stages compared to Si 94050 and Co 85036 salinity susceptible genotype. Patade et al., (2011) observed that the statistically significant higher SOD activity in salt (by $32 \%$ ) and PEG (by $27 \%$ ) stressed plants over the control. Chugh et al., (2011) reported that in maize SOD activity either slightly increased (in LM5 by $22 \%$ ) or remained unchanged (in Parkash) in tolerant genotypes under drought stress. Among sensitive genotypes, $\mathrm{PMH} 2$ and JH3459 were most severely affected and drought stress led to significant inhibition of SOD activity in leaf tissues of both the genotypes. Other genotypes namely Paras and LM14 were comparatively less affected and showed a decline of 48 and $15 \%$ in leaf SOD activity. The similar results are obtained in the present investigation.

\section{References}

Aebi, H. 1984. Catalase in vitro Methods Enzymol. Acd. Press, NY, 105: 121-126.

Agarwal, S. and Pandey, V. 2004. Antioxidant enzyme responses to $\mathrm{NaCl}$ stress in Cassia angustifolia. Biol. Plant. 48: 555-560.

Bin, Y., Dai, Q.L., Huang, S. and Zixia, W. 1996. Flooding induced membrane damage, lipid peroxidation and activated oxygen generation in corn leaves. Plant and Soils 179: 261-268.

Chugh, V., Kaur, N. and Gupta, A.K. 2011. Evaluation of oxidative stress tolerance in maize (Zey mays L.) seedling in response to drought. Indian J. Biochemistry Biophys. 48: 47-53.

Costa, H., Gallego, S.M. and Tomaro, M.L. 2002. Effect of UV-B radiation on antioxidant defense system in sunflower cotyledons. Plant Sci. 162(6): 939-945.

Dermiral, T. and Turkan, I. 2005. Comparative lipid peroxidation, antioxidant defense system and proline content in roots of two rice cultivars differing in salt tolerance. Environ. Exper. Bot. 53: 247-257.

Desikan, R., Cheung, M.K., Bright, J., Henson, D., Hancock, J.T. and Neill, S.J. 2004. ABA, hydrogen peroxide and nitric oxide signaling in stomatal guard cells. J. Exp. Bot. 55: 205-215.

Dhindsa, R.S., Plumb-Dhindsa, P. and Thorpe, T.A. 1981. Leaf senescence : Correlated with increased levels of membrane permeability and lipid peroxidation and decreased levels of superoxide dismutase 
and catalase. J. Expt. Bot. 32 (126): 93101.

Gomathi, R. and Rakkiyapan, P. 2011. Comparative lipid peroxidation, leaf membrane thermostabiliy and antioxidant system in four sugarcane genotypes differing in salt tolerance. Int. J. Plant Physiol. Biochem. 3 (4): 67-74.

Gomathi, R., Manohari, G. and Rakkiyappan, P. 2012. Antioxidant enzymes on cell membrane integrity of sugarcane varieties differing in flooding tolerance. Sugar Tech. 14 (3): 261-265.

Karpe, A., Nikam, A.A., Chimote, K.P., Kalwade, S.B., Kawar, P.G., Babu, H. and Suprasanna, P. 2012. Differential responses to salinity stress of two varieties (CoC 671 and Co 86032) of sugarcane (Saccharum officinarum L.) Afr. J. Biotechnol. 11(37): 9028-9035.

Kraus, T.E., Mckersie, B.D. and Fletcher, R.A. 1995. Paclobutrazol induced tolerance of wheat leaves to paraquat may involve increased antioxidant enzyme activity. J. Plant Physiol. 145: 570-576.

Lisson, S.N., Inman-Bamber, N.G., Robertson, M.J. and Keating, B.A. 2005. The historical and future contribution of crop physiology and modeling research to sugarcane production systems. Field Crops Res. 92: 321-335.

Miller, G., Suzuki, N., Ciftci-Yilmaz, S., and Mittler, R. 2010. Reactive oxygen species homeostasis and signalling during drought and salinity stresses. Plant Cell Environ. 33: 453-467.

Munns, R. and Termaat, A. 1986. Whole plant response to salinity. Aust. J. Pl. Physiol. 13: 143-160.

Nakano, Y. and Asada, K. 1987. Hydrogen peroxide is scavenged by ascorbate specific peroxidase in spinach chloroplasts. Plant Cell Physiol. 22: 867-880.

Pagariyaa, M.C., Devarumatha, R.M. and Kawara, P.G. 2012. Biochemical characterization and identification of differentially expressed candidate genes in salt stressed sugarcane. Plant Sci. 184: 113.

Parthasarathy, S.V. 1972. "Sugarcane in India". The K.C.P. Ltd., Madras- 6.

Patade, V.Y., Bhargava, S. and Suprasanna, P. 2011. Salt and drought tolerance of sugarcane under iso-osmotic salt and water stress: growth, osmolytes accumulation and antioxidant defense. J. Plant Interactions. 6(4): 275-282.

Sairam, R.K. and Saxena, D.C. 2000. Oxidative stress and antioxidants in wheat genotypes: Possible mechanism of water stress tolerance. J. Agron. Crop Sci. 184: 55-61.

Sairam, R.K. and Tyagi, A. 2004. Physiology and molecular biology of stress tolerance in plants. Curr. Sci. 86: 407-421.

Sekmen, A.H., Turkan, I. and Takio, S. 2007. Differential responses of antioxidative enzymes and lipid peroxidation to salt stress in salt tolerant plantago maritime and salt sensitive plantago media. Physiol. Plant. 131: 399-411.

Shalata, A. and Tal, M. 1998. The effect of salt stress on lipid peroxidation and antioxidants in leaf of the cultivated tomato. Physiol. Plant. 104: 167-174.

Venkataramana, S., Naidu, M.K. and Singh, S. 1997. Membrance thermostability and nitrate reductase activity in relation to water stress tolerance of young sugarcane plants. New Phytol. 107: 335-340.

\section{How to cite this article:}

Pote, C. L., P. S. Chougule, D. V. Shirsat, A. A. Kale, R. M. Naik, A. S. Jadhav, R. M. Garkar and Nimbalkar, C. A. 2019. Antioxidant Enzymes Respond to Osmotic Stress in the Leaves of Sugarcane (Saccharum officinarum L.). Int.J.Curr.Microbiol.App.Sci. 8(12): 1489-1495. doi: https://doi.org/10.20546/ijcmas.2019.812.178 